Article

\title{
Current Situation and Prospects for Aquifer Storage and Water Quality Enhancement (ASWQE) Projects in Korea: A Legal Perspective
}

\author{
Young-Gyoo Shim ${ }^{1}$ and Jae-Ho Choi ${ }^{2, *(D)}$ \\ 1 School of Law, Dong-A University (Bumin Campus), Busan 49236, Korea; youngs@dau.ac.kr \\ 2 Department of Civil Engineering, College of Engineering, Dong-A University (Seunghak Campus), \\ Busan 49315, Korea \\ * Correspondence: jaehochoi@dau.ac.kr; Tel.: +82-51-200-7623; Fax: +82-51-200-1419
}

Received: 15 April 2019; Accepted: 3 May 2019; Published: 14 May 2019

\begin{abstract}
The aquifer storage and water quality enhancement (ASWQE) method is a potential alternative to overcome the limitations of water resource policies that focus on surface water and act as an effective measure against water shortage caused by climate change. According to the physical/technical characteristics and operational complexity of the ASQWE, there are various legal/institutional issues to be considered at every stage in the development and implementation of the project. However, in Korea, there is no legislation or legal basis directly related to the ASWQE projects, resulting in large gaps between the initiatives of ASWQE and the relevant laws and statutes. In this respect, this study, to introduce approaches for the establishment of a legal system in line with the requirements of ASWQE projects, mainly analyzes the gaps between the abovementioned principal legal/institutional issues/subjects and the indispensable elements at each phase of the project's process in the existing Korean legal system concerning the ASWQE, particularly based on the issue tree approach. Through this comprehensive, systematic, and comparative case study, large gaps have been definitely identified between the initiatives surrounding ASWQE projects and the existing Korean legal system, and to conclude, legally multilateral approaches to fill and make up for the gaps have been presented. It is expected that the Korean government will continue to pursue the establishment of a comprehensive and integrated legal system in line with the requirements of ASWQE projects based on this research's findings. When these attempts succeed, the expected legal achievement for the development and implementation of ASWQE projects could serve as an exemplary legal case for the entire world.
\end{abstract}

Keywords: aquifer storage and recovery (ASR); aquifer storage and water quality enhancement (ASWQE); aquifer storage transfer and recovery (ASTR); Groundwater Act; groundwater regulations of Korea

\section{Introduction}

Various factors have led to the depletion and shortage of freshwater resources. The shortage of water resources is one of the most severe challenges facing humanity in the 21st century. Almost half of the world's population is expected to live in areas with water shortages by 2030 without stable water supplies [1], and this could trigger severe crises in terms of not only the natural environment and ecosystem, but also the quality of life and human health. As such, securing a stable, safe, and clean water supply has become a major focus of both governmental and nongovernmental organizations. Developing measures towards achieving such a resource is perceived as a key agenda for the sustainable development of the human race [2]. Clean and safe water is now considered a fundamental factor of 
human rights protection [3,4]. Currently, many countries are struggling to establish and implement national policies to secure stable, clean, and safe water resources [5].

Korea has been facing water shortages for many years due to frequent climate and weather anomalies, such as local and sporadic torrential downpours and repeated droughts. The Korean government has been making efforts to resolve this issue. In particular, extensive resources have been used to develop various policies and measures for using river water, as a means of preventing water shortages during droughts. In addition, substitutes for water resources, including groundwater, are being explored not only at the national government level, but also at the local government level. However, coping with this tough problem requires more fundamental solutions. Around the world, many improvements have been made in the development of various policies and technologies for securing clean water resources, and related regulatory and institutional infrastructures have been established. To keep up with such trends, Korea has been investigating various water resources at the national level, such as seawater desalination, groundwater dams, rainwater harvesting, artificial rainfall, riverbank filtrate, and deep sea water, all of which may assist the country in securing a stable supply of clean water [5,6].

Recently, Korea has been implementing the Aquifer Storage and Water Quality Enhancement (ASWQE) project in an effort to find reliable alternatives for water resources. This project, as a promising approach to managing various water resource issues emerging in Korea, can ensure water supply to a certain extent by making optimal use of the natural state of aquifers while also improving water quality. It is a positive and active technology that links surface water and groundwater in a complementary manner, and thus can help balance the pros and cons of using surface water and groundwater resources, such as by providing proactive measures for disasters and accidents due to water shortage and water quality deterioration, promotion of water security by diversifying water resources, elimination of social conflicts due to interregional water disputes, and cost reduction measures to secure clean water resources. Therefore, it is considered to be fundamentally different from the existing short-term technologies, which are considered negative and passive, for linking surface water and groundwater [7].

Many countries all over the world, such as the US, Australia, and some European, Asian and African countries, have been adopting various types of management of aquifer recharge (MAR) technologies as an effective alternative water management strategy to cope with water shortages due to climate change or global/regional environmental change [8]. In particular, many countries are showing great interest in aquifer storage and recovery (ASR)/aquifer storage transfer and recovery (ASTR) as part of an overall strategy to manage and use large-scale water resources [9-11]. For example, as of March 2010, the usage capacity of ASR (including ASTR) was 1 billion gallons per day $\left(3.79\right.$ million $\left.\mathrm{m}^{3} / \mathrm{d}\right)$, and this value is expected to increase to 5 billion gallons per day by 2020. As such, ASR is emerging as a key alternative to securing water resources worldwide [12].

Among various types of MAR, despite the practicality, usefulness, necessity, and economic feasibility of ASWQE as an alternative for securing alternative water resources, it has been regarded to have considerable obstacles and limitations to overcome in legal/institutional as well as physical/technical aspects, because the development of ASWQE technologies is at an early stage worldwide and even in its first attempt in Korea $[7,13]$. The critical issues, for example, which have been pointed out to address are injection well and aquifer clogging, collection and withdrawal efficiency of stored water, water quality and environmental pollution, etc. in the physical/technical dimension [8] and deficiencies in the integrated and systematic legal basis to effectively support the ASWQE project in the legal/institutional dimension [9].

Korea has been actively participating in this global trend and launched the ASWQE Research Group on 15 June 2013. The main goal of this research group is to develop and verify the total solution technologies required for the overall life-cycle of a groundwater reservoir, from the planning stage of ASWQE projects to the design, construction, and operation and maintenance (O\&M) stages. This group has been developing a pilot ASWQE project with a storage capacity of 1 million $\mathrm{m}^{3} / \mathrm{d}$ and source 
water production capacity of $2000 \mathrm{~m}^{3} / \mathrm{d}$ for drinkable water. The pilot project involves the following four phases:

(i) collection of raw water from the Nakdong River and pretreatment;

(ii) artificial injection into the aquifer at the nearby ASWQE site;

(iii) storage for a certain period of time and release;

(iv) recovery and supply of stored water to water treatment facilities [14].

However, the current legal system in Korea lacks regulatory/institutional support for the implementation of ASWQE projects. Quite a few countries around the world, especially some European countries, the US, and Australia, have been actively establishing and implementing regulatory/institutional/policy grounds and foundations, as well as plans for ASWQE projects. In contrast, Korea lacks even the basic legal concepts regarding ASWQE in terms of current related acts and subordinate statutes [6]. Therefore, not only the physical/technical aspects, but also the regulatory/institutional aspects should be established in Korea because they have been regarded as highly important factors for successfully commercializing and operating ASWQE.

This foundation is necessary for making accurate and rational decisions, and component policies can act to minimize inevitable uncertainties that are associated with the application of advanced scientific technology, such as in ASWQE projects. An overall framework can also provide clarity, which is absolutely necessary for carrying out and operating actual projects. In addition, clarifying the legal rights, obligations, and responsibilities of parties involved in a project is a prerequisite for carrying out and operating the projects $[9,15]$. Considering this situation, the main objectives of this study are to (i) analyze the various legal issues and current major legislation related to ASWQE projects in Korea and (ii) briefly introduce approaches and plans that could assist with the establishment of a legal system that reflects the requirements of ASWQE project implementation. To this end, this study mainly reviews and analyzes various legal issues regarding ASWQE projects.

\section{Definition and Main Legal Issues of ASWQE}

\subsection{Definition of ASWQE Projects}

ASQWE generally refers to "an aquifer and a series of facilities used to fill up the aquifer with surface water using an artificial method like a well or a pond, store it for a certain amount of time or let it flow and then pump it up" [13]. ASWQE projects involve injection/recharge and pumping facilities, pipe network facilities, pre- and post-treatment facilities, system detection facilities, and operating systems, but large artificial structures, such as tunnels, underground retaining facilities, or underground dams, are not required [7,13].

As shown in Figure 1, the ASWQE project involves highly complicated procedures and processes, such as the collection and pretreatment of source water, artificial injection into the aquifer, storage/filling/recharge, recovery/pumping, and water treatment/supply, all of which require highly intricate and complex legal legislation to be developed based on overseas and domestic legal and regulatory system benchmarking. Some examples include the legal status and water rights of the source water, i.e., surface water and stored groundwater; the legal status of the aquifer serving as the underground space for storage; the licensing basis and procedures for each phase of the project; subjects of the project; the purpose of using groundwater; a legitimate reward and compensation system; and the health and environmental standards in all phases of the project. Figure 1 represents that the method and procedure treating the source water, the water quality/quantity, and the environmental/health standards can be determined differently depending on the end use of the cleaned groundwater. 


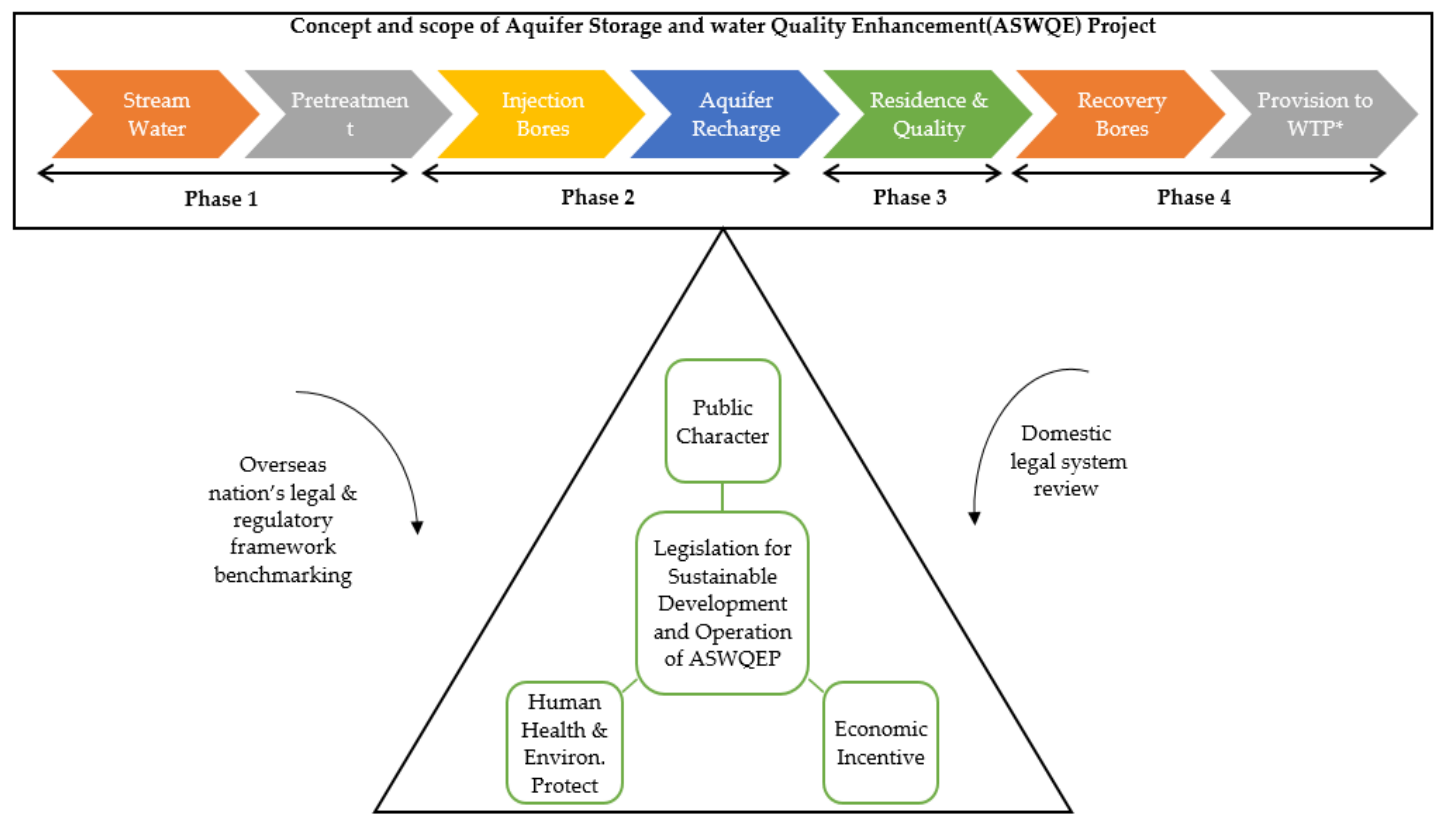

Figure 1. Concept and scope of the aquifer storage and water quality enhancement project (ASWQEP) and legislation requirements. WTP: Water Treatment Plant.

The principles of ASWQE are fundamentally equivalent to those of aquifer storage and recovery (ASR) or aquifer storage transfer and recovery (ASTR) technologies [14]. ASR and ASTR generally rely on the abundance of surface water during the rainy season. Surface water is injected into an aquifer and stored and recharged to form clean groundwater resources, which then can be pumped out for use mostly during the dry season [16]. The key difference between ASWQE and ASR/ASTR is that the former is used at all times to provide a constant supply of drinking water, while the latter is mainly used for storing water during rainy seasons and recovering the stored water during periods of water shortage for various purposes, such as emergency water provision during saltwater intrusion.

\subsection{Main Legal Issues}

In addition to the research and development (R\&D) activities related to the total solution technologies and the pilot project O\&M, the ASWQE Research Group is also conducting research on relevant regulatory/institutional foundations for the sustainable and reliable development and long-term operation of the ASWQE project. The authors used the issue tree analysis method [17] to identify the most pressing problems in relation to ASWQE project development and operation based on consultations and collaborative works with water resources and legal experts through a series of workshops. The authors derived major criteria and subjects considering the identified problem and then devised questions in relation to these subjects, using this as a foundation to compare and review the contents of domestic and foreign statutes, regulations, and policies (see Figure 2).

Many countries have tried to resolve various legal issues by establishing related acts and legislation either directly or indirectly. However, the authors could not find any cases of an integrated and uniform legal system at the national level up to now. For example, in the US, there have been some statutes relevant to ASR/ASTR projects at the federal level, such as the Clean Water Act, Underground Injection Control (UIC) Program under the federal Safe Drinking Water Act, etc., while several states have developed their respective UIC regulations, statutory schemes or programs of underground storage of water, drinking water standards, rules of water reuse or recycling, etc.. However, it has been pointed out that there are inconsistencies not only between the federal regulatory requirements and states' regulatory standards, but also between the Clean Water Act and the Safe Drinking Water Act [9]. 
Therefore, efficient establishment and implementation of a related legal system are considered a key factor in determining the success of such projects $[9,18]$.

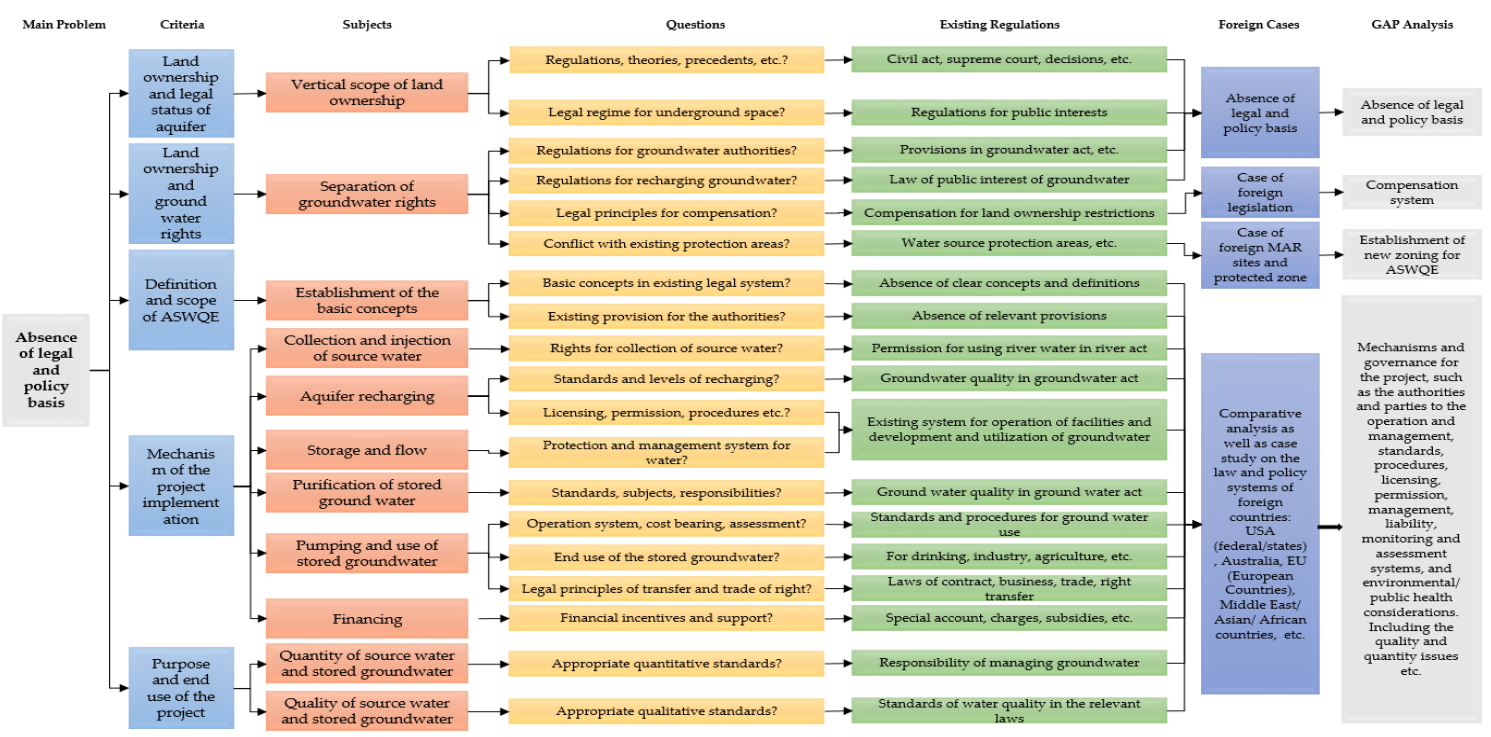

Figure 2. Issue tree analysis for the aquifer storage and water quality enhancement (ASWQE) projects in Korea. MAR: management of aquifer recharge.

Similar to other countries with experience in carrying out ASR/ASTR projects, such as the US, Australia, and several European Union countries, Korea also faces diverse and complicated legal issues for each phase of ASWQE projects. Legal issues that emerged throughout the various phases of the project were first analyzed (Figure 3). The blue boxes include prerequisites to be considered and addressed legally throughout the project, whereas the yellow boxes include individual items and factors to be considered and addressed at each stage in the implementation of the project.

Land Ownership and Right to Use Underground Space

(1) Separation of upper land ownership, right to use aquifer space to secure underground storage space

(2) Right to use and benefit from the created groundwater resource (water right)

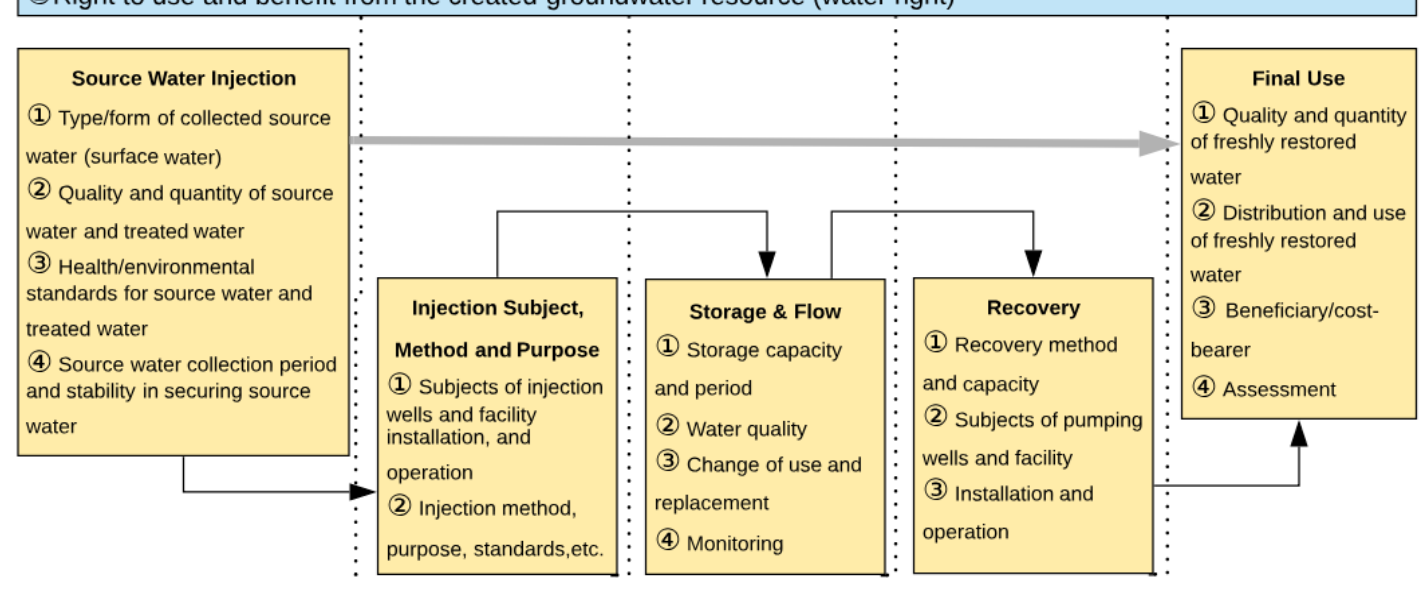

Procedural Matters \& Governance

(1) Subject of project implementation

(2) Project application and licensing basis and procedures

(3) Supervision agency of implementation, licensing and management

(4) Monitoring and assessment

(5) Decision making mechanism

Figure 3. Main legal issues and components in each phase of the ASWQE project. 
A few of the most essential issues can be summarized as follows: (i) separation between the rights to develop or use the aquifer to cope with groundwater shortages and the ownership of the land above the aquifer; (ii) rights to surface water that is used for aquifer storage; (iii) rights for groundwater injected and recharged in the aquifer; (iv) issues surrounding the purpose of pumping/supplying restored water and related rights; and (v) issues of governance, such as the subjects of implementing the project in all processes as well as licensing/permitting systems.

\section{Overview of the Existing Legal System Concerning ASWQE Projects}

Implementing and proceeding with ASWQE projects necessitates the development and use of groundwater resources and underground aquifers below certain land areas. Thus, a three-sided legal relationship is formed among the ownership parties of the land on the surface, underground spaces, and others with rights to develop and use groundwater resources. Depending on the acknowledgement of the specific scope and limitations of land laws above the surface, the legal status of the underground aquifer and the groundwater resources, as well as the right to develop and use them, may need to be clearly established. Groundwater is stored or allowed to flow through a certain underground space below the land. Thus, depending on whether the ownership of land above the surface extends to the underground space, or whether the land on the surface and groundwater in the underground space are considered as individual or inseparable objects, the legal relations regarding the ownership and rights to develop and use such resources among the three parties may vary regarding the ownership and rights to develop and use such resources among the three parties [5].

In Korea, laws that directly and indirectly regulate the legal status and rights of surface source water, i.e., surface water, and groundwater regarding ASWQE projects, the legal status of the underground storage space aquifer used for groundwater storage, its relationship with the land on the surface above the aquifer, and matters regarding groundwater development and use are distributed in various forms throughout private law and public law. Article 212 of the Civil Act, which is the typical general private law under the jurisdiction of Korea, defines the scope of land ownership, and Articles 235 and 236 regulate the rights to use groundwater through the mutual relationship of individual adjoining neighbors, thereby judicially regulating basic issues regarding ownership and usage of surface water/groundwater, land on the surface above the groundwater, and underground space related to ASWQE projects [6].

Regulations in public law that directly relate to the use of groundwater or related practices, or generally related acts having a close relationship with the concept and purpose of the ASWQE project, include the Groundwater Act, Water Supply and Waterworks Installation Act, River Act, Drinking Water Management Act, and the Act on Promotion and Support of Water Reuse. These acts define matters related to the legal status of groundwater, development/use, and preservation/management of groundwater in terms of public law depending on the legislative purpose and intent of individual acts. The Groundwater Act is the most fundamental mother law and general law in terms of managing, establishing, and implementing policies and plans for groundwater resources in Korea. It protects and controls the private activities of citizens regarding the development and usage of groundwater, while also institutionally regulating public control measures for the preservation and management of groundwater resources [6].

Among various other major public laws aside from the Groundwater Act that convey public legal regulations related to groundwater $[19,20]$, the Water Supply and Waterworks Installation Act, Drinking Water Management Act, River Act, and Act on Promotion and Support of Water Reuse are the most relevant to ASWQE projects. They include many elements and matters regarding the concept and scope of "aquifer recharge or underground reservoir" that serves as the basis for ASWQE projects [6].

There are other acts that also form the legal system related to clean water resources, such as the Framework Act on the National Land that forms the basis of the Comprehensive National Land Plan, which is a superior national policy regarding ASWQE projects; the River Act that forms the basis of the Long-Term Comprehensive Water Resource Plans; and the Groundwater Act that forms the 
basis of the Regional Groundwater Management Plans, as well as the Master Plan for Management of Groundwater. Furthermore, the Constitution of the Republic of Korea regulates the duty to protect the public nature of water, as well as national land and resources, and the duty to establish plans for balanced development and the use of such resources. Figure 4 shows an overview of the existing legal and policy system concerning ASWQE projects in Korea (Figure 4).

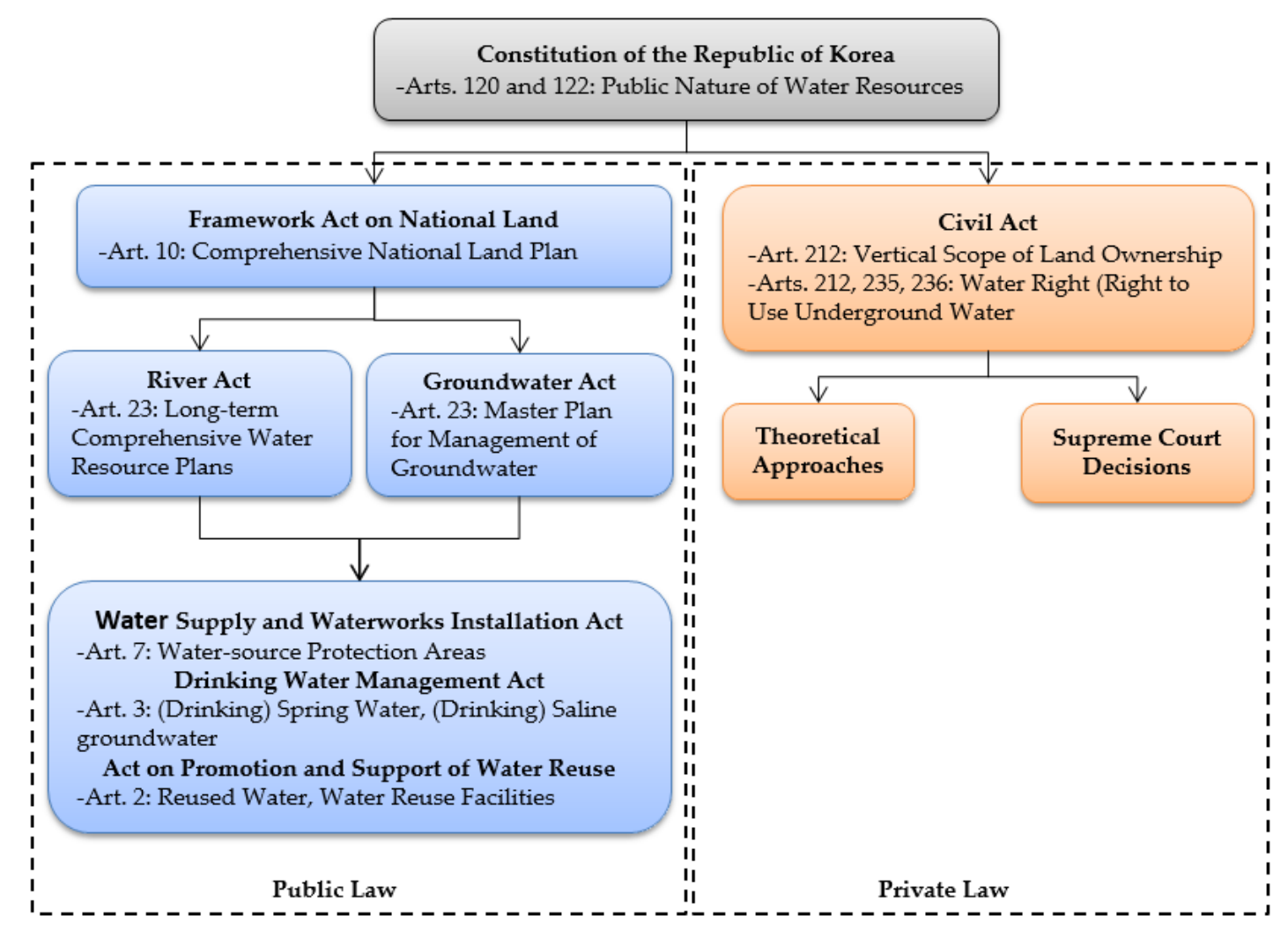

Figure 4. Overview of the existing legal and policy system concerning ASWQE projects in Korea.

\section{Legal Status of Groundwater According to Relevant Public Law}

\section{Principal Regulations and National Policy Related to Groundwater}

Article 120, Section 1 of the Constitution of the Republic of Korea, which is the uppermost and fundamental norm in Korea that forms the basis and foundation for all subordinate acts and national policies of the country, states that "Licenses to exploit, develop or utilize minerals and all other important underground resources, marine resources, water power, and natural powers available for economic use may be granted for a period of time under the conditions as prescribed by the Act". It is followed by Section 2, which states that "The land and natural resources shall be protected by the State, and the State shall establish a plan necessary for their balanced development and utilization". Moreover, Article 122 states that "The State may impose, under the conditions as prescribed by the Act, restrictions or obligations necessary for the efficient and balanced utilization, development and preservation of the land of the nation that is the basis for the productive activities and daily lives of all citizens". These articles clarify the public nature of water (water resources) as a part of the national land and resources and provide the basis for legal regulations for certain public interests.

The Framework Act on the National Land specifies the formulation of the Comprehensive National Land Plan (Article 9 of the same Act), including matters concerning the efficient utilization and management of national resources, such as land, water resources, forest resources, and marine resources, as well as matters concerning the rational utilization and management of underground spaces (Article 10 of the same Act). Therefore, the Comprehensive National Land Plan is the uppermost 
comprehensive national plan regarding the use, development, and preservation of national land. This can be arguably considered to form the basis for establishing and implementing national policies and plans about ASWQE projects, such as those pertaining to water resources including surface water and groundwater, as well as aquifers for groundwater storage.

Regarding water resources, the River Act, Groundwater Act, and Water Supply and Waterworks Installation Act individually serve as the acts that together form the basis of national policies regarding ASWQE projects. The River Act, which regulates basic matters concerning the management of river structures and facilities, preservation and management of river environments, and the use and management of river water, also emphasizes the public nature of water resources. It states that rivers and river water, which are public resources, shall be duly maintained to promote the public interest and that no private right shall be exercised against land consisting of a river and other river facilities (Article 4). The same act also makes it obligatory to establish the Long-Term Comprehensive Water Resource Plan as a comprehensive national plan for the stable supply of water resources and the efficient use, development, and preservation of rivers (water resources) (Article 23).

The Groundwater Act, which regulates basic matters concerning groundwater, such as the Master Plan for Management of Groundwater, permission for development and utilization of groundwater, and designations and management of groundwater preservation zones, also states that the State shall be held responsible for efficient preservation and management of groundwater and that the people shall cooperate in national policies for the preservation and management of groundwater and endeavor to preserve groundwater and to prevent the pollution thereof (Article 3). The same act also makes it obligatory to establish the Master Plan for Management of Groundwater as the uppermost national master plan concerning the development and utilization, as well as preservation and management of groundwater (Article 6).

In addition, the Water Supply and Waterworks Installation Act regulates basic matters concerning the installation and utilization of water-saving fixtures and water supply plans, designation and management of water source protection areas, and authorization for general waterworks businesses. The national policies and matters in this Act with close relevance to ASWQE projects are those concerning the formulation of basic plans for waterworks installation and management (Article 4), formulation of comprehensive plans for national waterworks (Article 5), and designation and management of water source protection areas (Article 7).

\section{Legal Definition and Status of Groundwater in the Groundwater Act}

The Groundwater Act is the most typical foundation law that has the most direct and closest relevance to ASWQE projects among the current related acts in Korea. Since the main goal of the ASWQE projects is to ensure a stable supply of clean groundwater using aquifers, the Act will regulate basic matters concerning groundwater for the proper development and utilization of groundwater and the prevention of the pollution thereof by prescribing matters concerning the appropriate development and utilization and the efficient preservation and management of groundwater (Article 1).

The Groundwater Act defines "groundwater", the object of application and regulation, as "water filling or flowing through spaces between strata or rocks beneath the Earth's surface" (Article 2, Section 1). Therefore, with this regulation alone, it is unclear whether the application scope includes only naturally formed groundwater in the aquifer or also artificially injected groundwater. Furthermore, contents with direct or indirect relevance to ASWQE projects in the Act include the master plan for management of groundwater, permission and reporting on development and utilization of groundwater, installation of facilities for securing groundwater resources, designation of groundwater preservation zones, registration of construction businesses for the development and utilization of groundwater, establishment of a special account for groundwater management, imposition and collection of charges for using groundwater, and others. Key provisions of the Act related to ASWQE projects are listed in Table 1. 
Table 1. Key provisions and contents related to the ASWQE projects in the Groundwater Act.

\begin{tabular}{|c|c|c|}
\hline \multicolumn{2}{|r|}{ Key Provisions } & \multirow{2}{*}{ Main Contents } \\
\hline Article & Title & \\
\hline Article 2 & Definitions & $\begin{array}{l}\text { The term "groundwater" means water filling or flowing through } \\
\text { spaces between strata or rocks beneath the Earth's surface. }\end{array}$ \\
\hline Article 6 & $\begin{array}{l}\text { Formulation of Master Plan } \\
\text { for Management of } \\
\text { Groundwater }\end{array}$ & $\begin{array}{l}\text { The Minister of Environment shall formulate a master plan for the } \\
\text { management of groundwater for every ten years for the systematic } \\
\text { development and utilization and the efficient preservation and } \\
\text { management of groundwater. }\end{array}$ \\
\hline Article 7 & $\begin{array}{l}\text { Permission for Development } \\
\text { and Utilization of } \\
\text { Groundwater }\end{array}$ & $\begin{array}{l}\text { A person who intends to develop and utilize groundwater shall } \\
\text { obtain prior permission from the head of a Si/Gun/Gu. } \\
\text { Groundwater impact investigation (report) }\end{array}$ \\
\hline Article 8 & $\begin{array}{l}\text { Reporting on Development } \\
\text { and Utilization of } \\
\text { Groundwater }\end{array}$ & $\begin{array}{l}\text { A person may develop and utilize groundwater after reporting in } \\
\text { advance to the head of a } \mathrm{Si} / \mathrm{Gun} / \mathrm{Gu} \text {. }\end{array}$ \\
\hline Article 9-6 & $\begin{array}{l}\text { Installation, etc., of Facilities } \\
\text { for Securing Groundwater } \\
\text { Resources }\end{array}$ & $\begin{array}{l}\text { The Minister of Environment and the head of a local government } \\
\text { may install and manage facilities for securing groundwater } \\
\text { resources (referring to groundwater dams, groundwater recharge } \\
\text { facilities, etc., installed and managed by the State or a local } \\
\text { government) in certain areas. }\end{array}$ \\
\hline Article 12 & $\begin{array}{l}\text { Designation of Groundwater } \\
\text { Preservation Zones }\end{array}$ & $\begin{array}{l}\text { Designation and management of certain areas as a groundwater } \\
\text { preservation zone by law. }\end{array}$ \\
\hline Article 22 & $\begin{array}{l}\text { Registration, etc., of } \\
\text { Construction Business for } \\
\text { Development and Utilization } \\
\text { of Groundwater }\end{array}$ & $\begin{array}{l}\text { Any person who intends to engage in construction business for the } \\
\text { development and utilization of groundwater shall register. }\end{array}$ \\
\hline Article 30-2 & $\begin{array}{l}\text { Establishment of a Special } \\
\text { Account for Groundwater } \\
\text { Management, etc. }\end{array}$ & $\begin{array}{l}\text { Establishment of a special account for groundwater management } \\
\text { and various support programs. }\end{array}$ \\
\hline Article 30-3 & $\begin{array}{l}\text { Imposition and Collection of } \\
\text { Charges for Using } \\
\text { Groundwater }\end{array}$ & $\begin{array}{l}\text { Charges for using groundwater shall be imposed upon and } \\
\text { collected from a person who develops and utilizes groundwater. }\end{array}$ \\
\hline
\end{tabular}

\section{Others}

Article 4 of the Groundwater Act states that "Where there are special provisions concerning the survey, development, utilization, preservation and management of groundwater in other Acts, such Acts shall govern the said activities". There are many public laws containing regulations related to groundwater aside from the Groundwater Act, and some typical examples with the closest relevance to ASWQE projects are the Water Supply and Waterworks Installation Act, Drinking Water Management Act, River Act, and the Act on Promotion and Support of Water Reuse. According to the Water Supply and Waterworks Installation Act, regulations of these same Acts are preferentially applied in the case of "raw water" or "water sources" that are the objects of application, even for the same groundwater (resource) (Article 3). Therefore, aquifer recharge in an underground reservoir can be designated as a "water resource protection area" according to the Water Supply and Waterworks Installation Act, and is thus included as the object of various regulations and management, which is likely to have direct impacts on ASWQE projects.

Moreover, the current legal system's Drinking Water Management Act has regulations related to "drinking water", "spring water", "drinking spring water", "saline groundwater", and "drinking saline groundwater", and thus, the Drinking Water Management Act has the status of a special law for the Groundwater Act. Therefore, for relevant matters, regulations of the Drinking Water Management Act will be applied first. Accordingly, if groundwater artificially recharged in aquifer recharge groundwater is categorized as "spring water" or "saline groundwater" according to the Drinking Water Management Act, it will be the object of various regulations and management in this act; this same act will also apply in terms of water quality standards. 
If river water is used as source water for ASWQE, issues of application and potential conflicts of clauses may arise regarding the use of river water under the River Act, and thus, the River Act is closely relevant to ASWQE projects. The Act on Promotion and Support of Water Reuse is in the status of a special law for the Groundwater Act and concerns matters of water reuse, and thus, regulations of the Act on Promotion and Support of Water Reuse will be applied first when using reused water as source water or water reuse facilities for ASWQE or other water reuse facilities. Therefore, it is necessary to additionally review the possibility of conflicts between the regulations of the Act on Promotion and Support of Water Reuse and ASWQE projects. Table 2 comprehensively reorganizes the major clauses and contents related to ASWQE projects in the River Act, Water Supply and Waterworks Installation Act, the Drinking Water Management Act, and the Act on Promotion and Support of Water Reuse, excluding the aforementioned Water Supply and Waterworks Installation Act and Drinking Water Management Act Groundwater Act.

Table 2. Key provisions and contents related to ASWQE projects in other laws.

\begin{tabular}{|c|c|c|c|}
\hline Name of Act & & ovisions and Main Contents & Relevance \\
\hline \multirow{3}{*}{$\begin{array}{l}\text { Water Supply and } \\
\text { Waterworks } \\
\text { Installation Act }\end{array}$} & Art. 3.1 & $\begin{array}{l}\text { "Raw water": Natural water that is } \\
\text { provided for drinking or industrial } \\
\text { purposes. }\end{array}$ & \multirow{3}{*}{$\begin{array}{l}\text { The Water Supply and Waterworks } \\
\text { Installation Act will apply prior to other } \\
\text { laws for underwater (resources) if it falls } \\
\text { under the category of "raw water" or } \\
\text { "water source", both of which are subject to } \\
\text { the Water Supply and Waterworks } \\
\text { Installation Act. } \\
\text { In this case, clean underground reservoirs } \\
\text { are also designated as a "water source } \\
\text { protection area" under the Water Supply } \\
\text { and Waterworks Installation Act and thus } \\
\text { are subject to various regulations and } \\
\text { management. This is likely to directly affect } \\
\text { businesses. }\end{array}$} \\
\hline & Art. 3.2 & $\begin{array}{l}\text { "Water source": The rivers, lakes, marshes, } \\
\text { groundwater, seawater, etc., within an area } \\
\text { where water intake facilities are installed so } \\
\text { that the water for drinking or industrial } \\
\text { purposes can be supplied. }\end{array}$ & \\
\hline & Art. 7 & $\begin{array}{l}\text { The Minister of Environment may designate } \\
\text { an area that is deemed necessary for } \\
\text { securing water sources and conserving the } \\
\text { quality of water as an area for the protection } \\
\text { of water sources (water source protection } \\
\text { area) or may modify the designation. }\end{array}$ & \\
\hline \multirow{4}{*}{$\begin{array}{l}\text { Drinking Water } \\
\text { Management Act }\end{array}$} & Art. 3.2 & $\begin{array}{l}\text { "Spring water": Naturally clear water in } \\
\text { bedrock aquifers, groundwater, or springs, } \\
\text { which can be safely maintained to be used } \\
\text { for drinking purposes. }\end{array}$ & \multirow{4}{*}{$\begin{array}{l}\text { As for the regulations regarding "spring } \\
\text { water", "drinking spring water", "saline } \\
\text { groundwater", and "drinking saline water", } \\
\text { the Drinking Water Management Act is a } \\
\text { special law as opposed to the Groundwater } \\
\text { Act, so the former prevails for the } \\
\text { aforementioned entities. } \\
\text { Therefore, if water resources in clean } \\
\text { groundwater reservoirs fall under the } \\
\text { category of "spring water", "drinking } \\
\text { spring water", "saline groundwater", or } \\
\text { "drinking saline water", the Drinking Water } \\
\text { Management Act will apply for their } \\
\text { regulations and management including the } \\
\text { water quality standard. }\end{array}$} \\
\hline & Art. 3.3 & $\begin{array}{l}\text { "Drinking spring water": Processed water } \\
\text { to make spring water potable by means of } \\
\text { physical treatment, etc. }\end{array}$ & \\
\hline & Art. $3.3-2$ & $\begin{array}{l}\text { "Saline groundwater": Groundwater in } \\
\text { bedrock aquifers, in which the contents of } \\
\text { salinity, etc., in dissolved form exceed the } \\
\text { standards prescribed by Ordinance of the } \\
\text { Ministry of Environment, and raw water to } \\
\text { be used for drinking purposes in a natural } \\
\text { state, the safety of which can be } \\
\text { continuously maintained. }\end{array}$ & \\
\hline & Art. 3.3-3 & $\begin{array}{l}\text { "Drinking saline groundwater": Processed } \\
\text { water to make saline groundwater potable } \\
\text { by means of physical treatment, etc. }\end{array}$ & \\
\hline \multirow{3}{*}{$\begin{array}{l}\text { Act on Promotion } \\
\text { and Support of Water } \\
\text { Reuse }\end{array}$} & Art. 2.1 & $\begin{array}{l}\text { "Reuse of water": Treating rain water, } \\
\text { sewage water, or wastewater in water reuse } \\
\text { facilities (herein referred to as "treated } \\
\text { water") for use in daily life, as well as for } \\
\text { industrial, agricultural, landscaping, and } \\
\text { river maintenance purposes. }\end{array}$ & \multirow{3}{*}{$\begin{array}{l}\text { The Act on Promotion and Support of } \\
\text { Water Reuse is in the status of a special law } \\
\text { for the Groundwater Act concerning } \\
\text { matters of water reuse, and thus, } \\
\text { regulations of the Act on Promotion and } \\
\text { Support of Water Reuse will be applied first } \\
\text { in using reused water as source water or } \\
\text { water reuse facilities for ASWQE. } \\
\text { There may be an issue with the application } \\
\text { and potential conflicting regulations in the } \\
\text { Act on Promotion and Support of Water } \\
\text { Reuse concerning ASWQE projects. }\end{array}$} \\
\hline & Art. 2.2 & $\begin{array}{l}\text { "Water reuse facilities": Rain utilization } \\
\text { facilities, water renewal systems, and } \\
\text { treated sewage and wastewater reuse } \\
\text { facilities. }\end{array}$ & \\
\hline & Art. 4 & $\begin{array}{l}\text { Matters regarding water reuse shall be } \\
\text { dictated by this act unless otherwise } \\
\text { prescribed under other acts. }\end{array}$ & \\
\hline
\end{tabular}




\section{Review and Assessment}

Korea has public laws closely related to the concept and purpose of ASWQE projects, such as the Groundwater Act, Water Supply and Waterworks Installation Act, Drinking Water Management Act, River Act, and the Act on Promotion and Support of Water Reuse. However, none of them directly regulate the development and utilization of ASWQE, nor do they establish or clarify definitions of concepts related to ASWQE. Therefore, a regulatory/institutional foundation for efficient implementation of the projects is lacking. In particular, the current legal system has inadequate or no regulations regarding ASWQE development or project systems (such as the legal system, organization, and exclusive workforce). Furthermore, it lacks the specificity and effectiveness of a national plan to proceed with the projects, and there are no specific strategies or legal support.

Major acts that directly use the terms groundwater (resource) and (artificial) recharge (facilities) include the Groundwater Act, Countermeasures against Natural Disasters Act, and Special Act on the Establishment of Jeju Special Self-Governing Province and the Development of Free International City. However, these regulations merely mention these terms as a strategy for securing groundwater resources (Article 9-6 of the Groundwater Act) or for overcoming drought (Article 32 of the Countermeasures Against Natural Disasters Act), or present them as approaches for using raw water (rainwater) in a specific area (Article 386 of the Special Act on the Establishment of Jeju Special Self-Governing Province and the Development of Free International City). Thus, these regulations are not sufficiently integrated as basic regulations for ASWQE projects.

\section{Vertical Scope of Land Ownership Under Relevant Private Law}

\section{Provisions of the Civil Act}

Article 212 of the Civil Act in Korea defines the scope of ownership of land only by stating that "Within the scope, where a justifiable profit exists, the ownership of land extends both above and below its surface", without a separate guideline regarding the specific scope or limitation of underground space concerning the land ownership, as well as the right to groundwater. As we have seen above, other public laws directly or indirectly related to underground space and groundwater, such as the Groundwater Act, do not provide separate regulations. Thus, regarding the ownership of underground space and groundwater, as well as the right to develop and utilize them, it becomes necessary to rely on the interpretation and custom of Article 212 of the Civil Act. However, this clause regulates as "within the scope, where a justifiable profit exists", thereby implying that the land ownership does not reach above and below its surface without any limits, but may be limited to a certain scope.

With advancements in scientific technology and expansions in the living space of humanity, effective exploitation and use of spaces above and below the ground has raised the need to clearly distinguish the ownership of land from the space above and below the surface of land and to establish legal registration methods for them [21]. Development and utilization of ASWQE also represents the increasing need and demand for the use of underground space. Therefore, it is necessary to clearly set up and organize the multidimensional legal relationship among the ownership of land, underground spaces, and groundwater.

\section{Theoretical Approaches and Cases of Legislation}

The current Civil Act in Korea sets the scope of land ownership "within the scope, where a justifiable profit exists". Therefore, whether the right to develop and use underground space and groundwater also belongs to the owner of the land above the underground space will be determined by the concept of "justifiable profit" in the same act, based on what standards exist and to what extent the scope can be acknowledged. Conventional theories, views, and cases of legislation focusing on such discussions are as follows.

First, the theory of unlimited land ownership is considered. According to this view, there is no limit to the scope of land ownership above and below the surface of land, and that the right of the 
landowner reaches the root of heaven above the Earth's surface and to the nucleus of the Earth below its surface. By extremely expanding the Roman law stating that the ownership of land reaches both above and below the land through the interpretation of Glossatoren, this theory is derived [22]. The German uniform law, French civil code, and Austrian law are typical cases of legislation that take this stance [23].

Second, the theory of limited land ownership is considered. According to this view, the scope in which land ownership has effect is limited to the "scope where a profit exists", as defined in the Korean Civil Act. This theory is divided into slightly different views in terms of specific standards and arguments or legal relations according to the scope of the limitation. However, they ultimately share the common view that the spatial scope of land ownership above and below the surface of land is not acknowledged to an unlimited extent, but is limited to a certain scope [5]. The civil laws in Korea, Japan, Germany, and Switzerland take this stance.

\section{Key Criterion for Vertical Scope of Land Ownership}

According to Article 212 of the Civil Act in Korea, the key issue in setting the scope of land ownership is what this "justifiable profit" means as well as its specific scope. It is recommended to determine the concept and scope of "justifiable profit" in terms of interpretation through specific business perspectives $[24,25]$. The concept of "justifiable profit" is ultimately relative, and the interpretation thereof may vary depending on the circumstances of the times or economic environment. Thus, it seems invalid to expand the effective scope of land ownership to an unlimited extent above and below the surface of land in the situation like today's, where land supply is limited, but the three-dimensional use demands for land both above and below its surface are rapidly increasing due to various factors. Therefore, the basic intent of Article 212 of the Civil Act lies in not permitting the prohibition of other people's use of the land above and below its surface unless it violates the profits of the landowner [5]. Therefore, it is not justifiable for landowners to ban an aeroplane from passing through the air above their land or a subway from passing through the underground without any reason. As such, claiming land ownership to an excessive extent may rather turn out to be an abuse of rights [26].

With regard to this, the court's precedent in Korea decided that the scope of "justifiable profit" should be "within the limits that can be controlled by humans", thereby presenting controllability as a requirement for the scope of land ownership [27]. However, being able to control does not always indicate that there is justifiable profit, and thus, some argue that it is more appropriate to mutually adjust and flexibly interpret the landowner's profits and public interests [28].

\section{Relationship between Land Ownership and the Right to Groundwater}

\section{Two Theoretical Approaches and the Supreme Court Rulings}

Clear setting of the relationship between land ownership and right to the groundwater is another key legal issue, because a clean underground reservoir and its groundwater artificially created by ASWQE project can be critically influenced by the legal rights of the property ownership. Herein, the relationship between land ownership and the right to groundwater are examined by focusing on (i) the view in which groundwater is considered a component of land and (ii) the view in which the two elements are considered individual entities.

According to the former, the right to groundwater is also part of land ownership and an object of land ownership. The landowner may use groundwater exclusively. In addition, Article 212 of the Civil Act can be applied to all cases regardless of whether the legal status of groundwater refers to hot springs, mineral springs, or mineral water, and regardless of how deep the groundwater is in relation to the surface of land [29]. There may be cases in which someone that is not the landowner has a separate right to use the groundwater, which is one of the limitations of land ownership by the legal principle of the adjoining neighbor relationship, stated as follows in Article 235 of the Civil Act: "Right 
to Use Water for Common Use: Adjoining neighbors have the right to use the wellspring or water supply for common use in proportion to their demands as long as they do not disturb the other's use of water".

As the issue of water deficiency is becoming more severe every day, interest in groundwater is also rapidly increasing worldwide. Consequently, active arguments are being held to distinguish the right to use groundwater from land ownership. There are various legal grounds for acknowledging groundwater as an independent object of real rights separate from the land. These different views have certain differences in perspective in terms of the argument that sees water rights for groundwater and land ownership as two individual rights. However, these views ultimately claim the two as rights with independent characteristics depending on the public nature of groundwater or special assets, the social need for groundwater as an important national resource, and the need to mediate conflicts of rights among stakeholders [5].

\section{Review and Assessment}

The legal characteristics and status of groundwater resources artificially formed in aquifers through ASWQE projects are different from those of naturally occurring groundwater. Therefore, the characteristics and contents of related rights are bound to differ from those of groundwater. Moreover, the issue of the ownership of ASWQE and groundwater resources, as well as the rights to develop, use, and dispose of them, may also vary depending on whether land ownership is separate from the right to use groundwater.

In determining whether the right to groundwater falls under the scope of the extent of land ownership, the recent precedent by the Supreme Court of Korea presented a standard under which the rights to use groundwater can be set by determining whether it directly affects public interests. Therefore, the use of groundwater in the scope that it does not directly affect public interests, such as naturally discharged groundwater, wells for domestic use or common use without use of a power system, or other minor developments or utilization, shall be included in land ownership, and thus, must be regarded as a right inherent to land ownership. However, development and utilization of groundwater beyond such an extent is not inherent to land ownership and is instead regulated by the administrative authorities concerned with the properties and functions of groundwater as a public water resource.

Furthermore, the possibility and scope for conceptualizing and regulating the right to groundwater as a separate and independent right from land ownership are being further expanded in certain cases pertaining to the Civil Act and various related acts, interpretations and customs of the court, and social/economic/environmental needs and purposes. Moreover, with the increasing needs and demands for the three-dimensional use of underground space, the effect of land ownership is limited to the scope of "justifiable profit". There are active discussions and attempts to define a standard as deep underground space where land ownership has no effect and to regulate it separately. In addition, there are normative attempts to separate the right to groundwater from land ownership by actively implementing the concept of groundwater for common use.

According to the observations made in this study, aquifers in which ASWQE projects are implemented can be generally regarded as spaces that exceed the scope of "justifiable profit", where ownership of the land affects the underground space and thus can be separated from land ownership. Moreover, groundwater resources recharged and formed through an ASWQE project can be conceptualized separately from land ownership based on legitimate grounds that view the right to groundwater as an independent right. 


\title{
12. Right to Surface Water (River Water) as a Major Source Water
}

\author{
ASWQE Method and Source Water Considerations
}

Currently, the groundwater reservoir technology being developed by the ASWQE Research Group in Korea can be divided into two types: one that injects and pumps water constantly, and another that injects water in the rainy season and pumps it in the dry season. The former type requires a stable supply of surface water throughout the year, even if the water quality is poor. This type can be installed in areas where aquifers are well developed (e.g., areas located in river fans or estuaries). To satisfy its requirements, river water is mainly used as source water. The latter type is suitable for areas where excessive surface water occurs only in the rainy season, such as in mountainous and coastal areas with poor river development. Thus, rainwater is used as the main source water [7].

\section{Legal Approaches of Foreign Countries: The US, Australia, and in the European Union}

Various forms of surface water, such as rainwater, river water, treated wastewater, and other recycled water, can be used as source water for ASWQE depending on the area of application or type of technology. Thus, legal rights to surface water can be considered one of the key legal issues that may affect ASWQE projects [9]. In the US, issues regarding the right to surface water are regulated by individual states. In general, states in the Eastern US preferentially grant the right to surface water to the landowner adjacent to the surface water, such as a river, based on the traditional concept of riparian rights. Nevertheless, the amount of use is limited and regulated through the permission of the state. On the other hand, states in the Western US grant the right to use water based on the prior appropriation doctrine or first-in-time, first-in-right principle, while also setting the scope of use according to the permission of the authorities $[6,9,30,31]$. In relation to ASR/ASTR projects, representative examples of states that have statutes concerning the right to surface water as source water, including permission provisions, can be Oregon (Or. Rev. Stat. §537.534 (2003)), Idaho (Idaho Code Ann. § 42-234(2) (2006)), Kansas (Kan. Admin. Regs. $\S \S 5-12-1$ et seq.), Arizona (Ariz. Rev. Stats. $\S \S 45-801.01$ et seq.), California (Cal. Water Code § 1242 (2006)), and Texas (Tex. Water Code Ann. § 11.153 (2005)) [9].

Meanwhile, according to the prior appropriation doctrine, surface water may be treated separately from groundwater since the surface water is regulated by the state's permit system based on the doctrine of priorities, while the right to groundwater is considered to be part of private land ownership [32]. As stated above, ASWQE projects use various forms of surface water which are physically, hydrologically, or environmentally connected with groundwater. They mutually and continually influence each other through channels. Therefore, the integrated or conjunctive management system has been pointed out as an important element in performing ASWQE projects [9,33]. In the US, particularly in the western states in which surface water and groundwater are regulated under the prior appropriation doctrine, judicial decisions and laws have established the "groundwater-surface water management" (or "conjunctive management") system of surface water and groundwater. They have considered the conjunctive management system as an essential part for ASR projects [34]. In 1976, the US Supreme Court ruled that "groundwater and surface water are physically interrelated as integral parts of the hydrologic cycle" [32,35]. Wyoming, Idaho, Colorado, and Washington are representative cases that have some common provisions relating to the conjunctive management based on the prior appropriation doctrine as the guiding principle in their constitutions or statutes (Wyoming Constitution, Art. 8 §; Idaho Constitution, Article XV § 3; Colorado Constitution, Article XVI § 6) [33,34].

In Wyoming, anyone who wants to use groundwater must apply to the State Engineer for permission (Wyoming Statute $\S 41-3-930(a)$ ). If the surface water and groundwater in a specific area are determined to constitute "one source of supply" by the State Engineers, they shall be managed under a single set of priorities (Wyoming Statute $§ 41-3-916$ ). The Board of Control, the state authorities to administer groundwater supplies, may designate particular areas as "control areas" under certain circumstances (Wyoming Statute $\S$ 41-3-912). Similarly, permission is necessary to appropriate groundwater in Idaho (Idaho Code $\S 42-202$ ). In Idaho, the Idaho Department of Water Resources 
(IDWR) is the state authority responsible for both administering and developing rules and regulations for not only surface water, but also groundwater. Through these mechanisms, Idaho establishes a comprehensive legal system for conjunctive management applying to "areas determined to have a common groundwater supply" (Idaho Administrative Procedure Act, Section 37).

In Colorado and Washington, the doctrine of priority appropriation commonly applies to both surface water and groundwater. Colorado divides groundwater regulation and management into three categories: groundwater located in a nondesignated groundwater basin, groundwater located in a designated groundwater basin, and groundwater located in a Denver groundwater basin. Among them, especially the first type is presumed to be "tributary", so the groundwater falls within a single set of priorities with surface water (Colorado Revised Statutes § 37-92-102, 2008). However, it may be determined to be "nontributary groundwater" because the presumption is rebuttable. In the case of nontributary groundwater, there is a restriction that the surface flow depletion should not exceed $0.1 \%$ of the groundwater withdrawal rate (Colorado Revised Statute $\S 37-92-102,2008$ ). In Washington, the Washington Department of Ecology (WDE) administers the permit system for both surface water and groundwater (Revised Code of Washington $\S 90.44 .050,2008$ ). According to the groundwater code of Washington, the potential interrelationship between them is acknowledged (Revised Code of Washington $\S 90.44 .030,2008$ ). If it is determined that there is a "significant hydraulic continuity" between surface water and groundwater, they must be managed under a single set of priority rules or appropriation regime (Washington Administrative Code § 173-549-060, 2008).

Australia established regulatory/institutional grounds including relevant licensing systems for groundwater injection and recovery using rainwater, treated wastewater, and other types of surface water relatively early. Based on the concept of the public nature of water resources, authorities in Australia are in charge of the comprehensive regulation and management of water resources, from granting and distributing of the rights to rainwater and reclaimed water to the artificial injection, recovery, and distribution of such water $[6,14]$. In terms of integrated management for surface water and groundwater, some areas in Australia have an allocation system similar to that of the US. In Australia, however, it is not the general approach to regulate the rights to surface water and groundwater together, which is common in some western states of the US. Moreover, in comparison with the cases of these states, the clear definition of property rights relating to ASR projects in Australia (e.g., rights to surface water) is lacking, which is a critical impediment to ASR in Australia [33].

Most European Union countries do not have an integrated domestic law regarding direct application and regulation of ASR/ASTR projects, with only a few exceptions: Spain and Switzerland. They individually establish and implement management policies based on the general laws concerning water resource management $[6,18,30,36]$. Therefore, the issue of legal rights to surface water regarding ASWQE projects cannot be determined uniformly and accurately with only the relevant legal system itself.

\section{Interpretation and Application of the Relevant Provisions of Korean Laws}

In Korea, the general rights to use surface water are regulated by the Civil Act. The landowner may not interfere with the natural flow of water coming from adjoining land (Article 221, Section 1), and the landowner of upstream may not interfere with the natural flow of water necessary for and that flowing down onto the adjoining downstream land by diverting more water than is necessary for reasonable use (Article 221, Section 2). Therefore, the private law in Korea does not grant a specific person with exclusive rights to naturally formed and flowing surface water and it adequately distributes and protects the right to use water within a reasonable scope among owners of adjoining lands in light of the public nature of water. The precedents also decided that drawing water from upstream surface water is permitted within the scope of not hindering that of downstream [37]. However, if water flows through private land, the water rights of others are not approved and only the owner of the relevant land is granted the exclusive rights [30]. The precedents also do not approve of the acquisition right in 
the laws or existence of customary laws that are against the above $[38,39]$. This is because, in this case, water flowing over privately owned land is a component of the ownership of the relevant land [40].

In the case of river water, the Civil Act states that those engaged in agriculture and industry on the banks of public rivers may draw necessary water from the river for use in their business as long as they do not disturb the use of water by other persons rightfully entitled to such use (Article 231, Section 1), and structures necessary for drawing water under the preceding paragraph may be constructed (Article 231, Section 2). This is referred to as the right of using public rivers, and the right to use water at a lower part can be protected within a justifiable scope (Article 232), while the rights and duties may be the object of succession by law (Article 233).

With regard to the precise legal status and properties of the right of using public rivers, there are two perspectives: (i) the theory of independent water rights and (ii) the theory of adjoining neighbors rights. The former sees the right to use public rivers as an independent water right, and it claims that, by common law, this right is conceptualized as an independent legal right, and thus, if multiple rights to use public rivers are in conflict, the vested rights are protected by giving a clear priority to the existing water rights according to the prior appropriation doctrine. This is the majority view and the stance of the precedents. Conversely, the latter sees the right to use public rivers based on adjoining neighbors rights, and it claims that this right is not granted to a specific landowner, but is approved for anyone engaged in agriculture or industrial work in the coastal areas or a public river. Moreover, related regulations in private law are not set up to grant certain property rights to a specific individual, but they are aimed at adjusting water use among adjoining neighbors, and this right to use public rivers is included in the clause of adjoining neighbors in this private law [31].

The River Act has been enacted in Korea as a special law to be preferentially applied before the Civil Act regarding river water. According to the River Act, a person who intends to use river water shall obtain permission from the Minister of Land, Infrastructure, and Transport (Article 50). Relevant vested rights may be protected in cases where the water rights can be clearly proved to have been obtained by common law prior to the enforcement of the River Act [41]. In addition, the River Act regulates matters concerning the protection of vested river users, principles of use and distribution of river water, reports on temporary use of river water, instream flows, use and management of river water, adjustment in use of river water, and mediation of disputes over river water. Therefore, these regulations may be applied when using river water as the source water for ASWQE.

Regarding the issue of integrated or conjunctive management for surface water and groundwater, Korea has blind spots in legislation as well as policy. In Korea, according to the relevant laws, groundwater and surface water are treated separately. For example, groundwater is regulated according to the Groundwater Act, while surface water (river water) is regulated according to the River Act. Despite their interconnectivity and interdependency in physical, hydrological, and environmental aspects, there are no statutes or regulations considering these characters. Therefore, the integrated legislation to perform ASWQE projects in Korea, a final goal of the ASWQE Research Group, will be the leading case of the conjunctive management in Korea.

\section{Conclusions and Future Research Outlook}

In order to develop legal and institutional bases for practical and sustainable execution of ASWQE projects, institutional mechanisms and governance that are supported by the law and regulations are indispensable for the effective execution of ASWQE projects. Although the entire process of ASWQE projects engender many diverse and complex legal issues, the existing relevant legal system and regulations have proven to be insufficient for forming valid legal and institutional bases to commence such projects. Current Korean statutes and regulations have not even established legal notions, nor recognized the essentials regarding ASWQE, such as the legal status of groundwater and its associated rights and rules, upper and lower spatial ranges of land ownership and the legal status of aquifers, issues of water rights regarding groundwater and source water, and other issues regarding public health, environment, permit standards, etc. In the current Korean legal sphere, private laws such as 
the Civil Act and public laws such as the Groundwater Act overlap in multiple aspects. Furthermore, the legal framework has to be altered in an optimal way to include the ASWQE system by which the existing statutes can accommodate the system without decommissioning the advantages of the ASWQE from any one given perspective.

Through the reviews and analyses, large gaps could be clearly identified between the initiatives surrounding ASWQE projects and the existing Korean laws and statutes. Throughout this research project, the authors have examined and suggested three different legal and institutional approaches in order to fill and make up for the gaps: (i) to reform and revise the existing statutes, especially the Groundwater Act; (ii) to make a new special law, tentatively named "the Act on Aquifer Recharge, Use, and Management of Groundwater"; and (iii) to integrate ASWQE projects into the Nation's Water Industry Fostering Strategies, which is being planned and propelled by the Korean government. The last approach will need more comprehensive national policy and legislation, in which ASWQE is included as a significant part.

The ASWQE Research Group has continually compared and examined the three approaches to find out and suggest the optimum proposal. From our observations, if this effort is successful, the Korean government will be able to establish the integrated legislation to perform ASWQE projects successfully in Korea. Further, the achievement could serve as an exemplary legislative model not only to form the legal and institutional foundation for Korea's ASWQE business, but also to become a pioneer of the global ASR/ASTR industries. The concrete legislative improvements are expected to be introduced in the near future.

Author Contributions: Y.-G.S. has mainly written this article, and J.-H.C. has completed this article through editing.

Funding: This research was supported by a grant (code 17AWMP-B066761-05) from the AWMP Program funded by the Ministry of Land, Infrastructure, and Transport of the Korean government. And this research and the APC were funded by the Basic Science Research Program through the National Research Foundation of Korea (NRF) funded by the Ministry of Education (2016R1A6A1A03012812).

Acknowledgments: I would like to express my gratitude to Nam-sik, Park and Jung-jae, Lee, respectively in the department of civil engineering and in the department of architectural engineering at Dong-A university for providing advice and research guidance for this article.

Conflicts of Interest: The authors declare no conflicts of interest.

\section{References}

1. UNESCO. Strategies for Managed Aquifer Recharge (MAR) in Semi-arid Areas. Gale, I., Ed.; 2016. Available online: http://unesdoc.unesco.org/images/0014/001438/143819e.pdf (accessed on 16 December 2016).

2. UNESCO. The United Nations World Water Development Report 2015: Water for a Sustainable World. 2015. Available online: http://unesdoc.unesco.org/images/0023/002318/231823E.pdf (accessed on 4 January 2017).

3. Mechlem, K. Groundwater governance: The role of legal frameworks at the local and national level-Established practice and emerging trends. Water 2016, 8, 347. [CrossRef]

4. UN General Assembly. Resolution A/RES/64/292: The Human Right to Water and Sanitation, Adopted on 28 July 2010. Available online: www.un.org/en/ga/search/view_doc.asp?symbol=A/RES/64/292 (accessed on 3 March 2017).

5. Son, J.E.; Shim, Y.G.; Choi, J.H. A review on the land ownership for development and use of clean underground storage of water-From the prospect of legal policy for development and use of clean underground storage of water. J. Law Political Res. 2014, 14, 1553-1580. [CrossRef]

6. Shim, Y.G.; Choi, J.H. A study on the establishment of legal institution for the Project of Aquifer Storage and Water Quality Enhancement in Korea-With special reference to the comparative approach to the legal institutions. J. Law Political Res. 2015, 15, 1381-1421.

7. Park, N.S.; Kim, H.J.; Lee, S.H. Introduction and overview of the Aquifer Storage and Water Quality Enhancement Research Group. Water Future 2013, 46, 10-18.

8. Kim, Y.C.; Kim, Y.J. A review on the state of the art in the management of aquifer recharge. J. Geol. Soc. Korea 2010, 46, 521-533. 
9. N.A.S. Committee on Sustainable Underground Storage of Recoverable Water, National Research Council, National Academies of Sciences. Prospects for Managed Underground Storage of Recoverable Water; The National Academies Press: Washington, DC, USA, 2008.

10. Ward, J.; Dillon, P. Robust Policy Design for Managed Aquifer Recharge; Waterlines Report Series No. 38; National Water Commission: Canberra, Australia, 2011. Available online: Apo.org.au/system/files/23758/ apo-nid23758-101866.pdf (accessed on 10 June 2016).

11. Wilson, D. The feasibility of using aquifer storage and recovery to manage water supplies in Georgia. In Proceedings of the 2007 Georgia Water Resources Conference, Albany, GA, USA, 27-29 March 2007; Available online: https://smartech.gatech.edu/bitstream/handle/1853/48234/Wilson_7.2.3.pdf?sequence=1\&isAllowed= y (accessed on 22 September 2016).

12. Global Water Intelligence (GWI). Market profile: Aquifer storage and recovery. GWI Mag. 2013, 11, 33-36.

13. Park, N.S. Planning and Research Report of Technology for Aquifer Storage and Water Quality Enhancement; Land Transport and Maritime R\&D Report; Korea Institute of Construction \& Transportation Technology Evaluation and Planning; Ministry of Land, Transport and Maritime Affairs: Seoul, Korea, 2012.

14. Choi, J.H.; Shim, Y.G.; Oh, C.R. A study on the basic approach for legal framework of aquifer storage and water quality enhancement project in Korea-With special reference to the consideration on and analysis of the Australian legal system of managed aquifer recharge (MAR). J. Law Political Res. 2015, 15, 561-589.

15. Seerley, D.J.W. An Analysis of the Evolution of Public Policy for Aquifer Storage and Recovery: Experiences in Three Southeastern States. Ph.D. Thesis, The University of Georgia, Athens, GA, USA, 2003.

16. Pyne, R.; David, G. Groundwater Recharge and Wells: A Guide to Aquifer Storage Recovery; Lewis Publishers: Boca Raton, FL, USA, 1995.

17. Davis, I.; Keeling, D.; Schreier, P.; Williams, A. The McKinsey Approach to Problem Solving; McKinsey Staff Paper No. 66; McKinsey \& Company, Inc.: New York, NY, USA, 2007; Available online: https://drive.google.com/file/ d/0B8QPsQ-9eAMBOWl2SnBKSEJLYWc/edit (accessed on 17 July 2015).

18. Wintgens, T.; Hochstrat, R.; Kazner, C.; Jeffrey, P.; Jefferson, B.; Melin, T. Managed Aquifer Recharge as a Component of Sustainable Water Strategies; IWA Publishing: London, UK, 2012; Chapter 22.

19. Hahm, T.S. A Study on the Improvement of Ground Water Legislation; Korea Legislation Research Institute (KLRI): Seoul, Korea, 2007.

20. Moon, H.J. Policies for the Rational Utilization and Management of Groundwater Resources; Korea Environment Institute (KEI): Seoul, Korea, 2007.

21. Lim, H.T.; Seo, Y.S. A Study on the Registration Method for Underground Geospatial Information; Korea Cadastral Survey Corporation, Spatial Information Research Institute: Seoul, Korea, 2014.

22. Kim, H.T. Multi-dimensional scope of land ownership and the problem of public notification system. Yeungnam Law J. 2013, 37, 237-255.

23. Ryu, S.H.; Ryu, C.H. Rational Limitations and Efficient Use of Land Ownership; Sun Moon University 21C Regional Development Institute, Sun Moon University: Asan, Korea, 2001.

24. Lee, E.Y. Property Law; Parkyoungsa: Seoul, Korea, 1998.

25. Lee, Y.J. Property Law; Parkyoungsa: Seoul, Korea, 1997.

26. Kim, S.Y. Property Law; Bobmunsa: Seoul, Korea, 1999.

27. Supreme Court Decision 4293Minsang204 Decided 19 October 1961. Available online: http://www.law.go.kr/ precInfoP.do?precSeq=86658 (accessed on 12 April 2017).

28. Ko, S.R. Property Law; Bobmunsa: Seoul, Korea, 2001.

29. Lee, Y.J. (Ed.) Commentary on Property Law (I); Korea Judicial Administration Society: Seoul, Korea, 1991.

30. Burchi, S. Study on the Legislative Framework Regulating the Recharge of Aquifers with Adequately Treated Wastewater. Sustainable Water Integrated Mechanism (SWIM)_Support Mechanism. European Union, 2014. Available online: http://www.swim-sm.eu/files/Legislative_framework_regulating_the_recharge_of_ aquifers_EN.pdf (accessed on 7 November 2016).

31. Park, H.R. Comparative study on Korean water law and American water law. Hum. Rights Justice 2005, 348, 68-86.

32. Hill Country Alliance (HCA). Issue: Surface and Groundwater Policy Integration. HCA Issue Papers. Available online: http://www.hillcountryalliance.org/uploads/HCA/SW_GWPolicyIssuePaper2.pdf (accessed on 1 August 2017). 
33. Nelson, R. Instituting Integration: Findings of the Comparative Groundwater Law \& Policy Program's Workshop 1. October 17-19, 2001 at Stanford University, Water in the West Workshop Paper 3. May 2012. Available online: http://waterinthewest.stanford.edu/sites/default/files/RNelsonWorkingPaper3.pdf (accessed on 1 August 2017).

34. Ogden, F.L.; Harm-Benson, M. Integrated Management of Groundwater and Surface Water Resources: Investigation of Different Management Strategies and Testing in a Modeling Framework; Final Report. Wyoming State Engineer's Office: Cheyenne, WY, USA, 2010. Available online: http://www.uwyo.edu/owp/_files/finalrptp20ogden.pdf (accessed on 2 August 2017).

35. Supreme Court Decision 99Du7470 Decided 23 October 2001. Available online: http://www.law.go.kr/LSW/ precInfoP.do?mode=0\&precSeq=192631 (accessed on 13 April 2017).

36. Miret, M.; Vilanova, E.; Molinero, J.; Sprenger, C. The Management of Aquifer Recharge in the European Legal Framework. DEMEAU, EC's Seventh Framework Programme. 2012. Available online: http://demeaufp7.eu/sites/files/D121\%20legal\%20framework\%20and\%20MAR\%20DEMEAU\%20project_1.pdf (accessed on 16 September 2016).

37. Supreme Court Decision 65Da1736 Decided 9 November 1965. Available online: https://glaw.scourt.go.kr/ wsjo/intesrch/sjo030.do?q=65\%EB\%8B\%A41736\&tabGbnCd=\#// (accessed on 16 April 2017).

38. Supreme Court Decision 66Da397 Decided 3 March 1966. Available online: https://glaw.scourt.go.kr/wsjo/ intesrch/sjo030.do?q=65\%EB\%8B\%A41736\&tabGbnCd=\#1557387334451 (accessed on 16 April 2017).

39. Supreme Court Decision 66Da1382 Decided 30 May 1967. Available online: http://www.law.go.kr/LSW/ /precInfoP.do?precSeq=154084 (accessed on 16 April 2017).

40. Lee, K.W. Water use rights on civil law. Land Law 2000, 16, 151-170.

41. Supreme Court Decision 72 Da78 Decided 31 March 1972. Available online: https://glaw.scourt.go.kr/wsjo/ intesrch/sjo030.do?q=65\%EB\%8B\%A41736\&tabGbnCd=\#// (accessed on 17 April 2017).

(C) 2019 by the authors. Licensee MDPI, Basel, Switzerland. This article is an open access article distributed under the terms and conditions of the Creative Commons Attribution (CC BY) license (http://creativecommons.org/licenses/by/4.0/). 